\title{
PERFORMANCE OF A LATEX AGgLUTINATION TEST IN THE DIAGNOSIS OF ACUTE GASTROENTERITIS BY ROTAVIRUS
}

\author{
Thais Lourenço Ferreira $^{1}$; Mariana Costa Becho ${ }^{1}$; Aline Rodrigues Bernardo ${ }^{1}$; Thaís Castelo Branco Chaves ${ }^{1}$; \\ Rosemary Suely Ribeiro²; Jurandir Sampaio de Lima²; Alexandre Madi Fialho ${ }^{3}$; José Paulo Gagliardi Leite; \\ Carlos Mazur ${ }^{1}$; Maria das Graças Miranda Danelli ${ }^{1 *}$
}

${ }^{1}$ Laboratório de Viroses Veterinárias. Instituto de Veterinária. Universidade Federal Rural do Rio de Janeiro; ${ }^{2}$ Laboratório de Viroses. Departamento de Patologia Clínica. Instituto Fernandes Figueira, FIOCRUZ/RJ; ${ }^{3}$ Laboratório de Virologia Comparada, Departamento de Virologia, Instituto Oswaldo Cruz, FIOCRUZ/RJ

Submitted: July 01, 2005; Returned to authors for corrections: April 20, 2006; Approved: October 13, 2006

\section{SHORT COMMUNICATION}

\begin{abstract}
The aim of this work was to determine the performance of latex agglutination test (LAT) for evaluating children acute gastroenteritis by rotavirus. The LAT showed good sensitivity, as well as specificity and predictive positive value and due to its simplicity and speed, it has been suitable for rotavirus diagnosis in hospital laboratories.
\end{abstract}

Key words: Rotavirus, diagnosis, latex agglutination test, poliacrylamide gel electrophoresis

Rotavirus Group A has represented the most ordinary cause of worldwide childhood acute diarrhea. In developed countries, it was estimated that gastroenteritis associated to these etiological agents has been responsible for 600.000 to 870.000 deaths/year, which means 20 to $25 \%$ of deaths due to diarrheic diseases, as well as $6 \%$ of global mortality among children below five years old (5). This agent has been responsible for $70 \%$ of 0 to 2 years old children diarrhea events; however, studies performed in some Brazilian cities showed the presence of a serotype reaching both adults and children at school age (4). Studies carried out in hospitals have reported that prevalence of diarrhea by rotavirus ranges from $12 \%$ to $42 \%$ (5).

Several techniques have been developed for rotavirus diagnosis. In the first rotavirus surveys, the viral agent detection was performed by electronic microscopy (EM); afterwards, others techniques were developed, such as poliacrylamide gel electrophoresis (PAGE), immunofluorescence (IF), radioimmunoassay (RIA), reverse passive hemagglutination (RPH), immunoenzimatic assay (IEA), latex agglutination test (LAT) and, more recently, a reverse transcription polimerase chain reaction (RT-PCR) and immunochromatography (IMC) $(1,2,3,6,7)$. Among these assays, LAT has been reported as a simple and fast assay, as required for rapid diagnosis and illness control on hospital level. However, the sensitivity and specificity of LAT may vary according to the commercial kit used. This work aimed to evaluate the performance of LAT kits for rotavirus diagnosis in two Rio de Janeiro State Hospitals.

Eighty eight fecal samples from children with acute gastroenteritis, collected from June, 2000 to April, 2004 at Instituto Fernandes Figueira (IFF) - Fundação Oswaldo Cruz (FIOCRUZ) and at the Hospital de Assistência Médica Infantil de Urgência (AMIU), Jacarepaguá, Rio de Janeiro State, Brazil, were analyzed. The samples were collected in sterile recipients and sent to IFF laboratory for immediate testing using LAT, and subsequently forwarded to the Laboratório de Viroses Veterinárias, located at Instituto de Veterinária da Universidade Federal Rural do Rio de Janeiro, Brazil, for confirmation. The samples were maintained at $-20^{\circ} \mathrm{C}$ until submetted to nucleic acids extraction and PAGE.

*Corresponding author: Departamento de Microbiologia e Imunologia Veterinária, Instituto de Veterinária, UFRRJ. BR 465, Km 07, 23890-000, Seropédica, RJ, Brasil. E-mail: danelli@ufrrj.br 
The samples were tested by Slidex Rota-Kit $2^{\circledR}$ (BioMérieux). A sample was considered positive for rotavirus when agglutination was observed within two minutes reaction, as recommended by the kit manufacturer.

For the poliacrylamide gel electrophoresis (PAGE), a ten percent suspension of fecal matter was prepared in $0.1 \mathrm{M}$ TrisHCL, pH 7.3. Furthermore, freon treatment and glass beads for mucus and fat removal were used. The nucleic acid, obtained by phenol-chloroform extraction, was ressuspended in electrophoresis sample buffer (9). The extracted nucleic acid was fractionated on $7.5 \%$ poliacrylamide gel. The RNA migration patterns were visualized after silver nitrate gel staining. RNA extracted from simian rotavirus (SA11) was used as positive control on PAGE analysis. Fecal samples were considered positive when their electrophoretic profile presented 11 RNA slabs, similar to the positive control pattern.

The samples with incompatible results in relation to the two techniques were tested by IEARA, a immunoenzimatic assay for detection of rotavirus and adenovirus antigens (BioManguinhos, RJ, Brazil) (8). This assay is a double sandwich method, in which the antigens are captured by antibodies in goat hiperimune serum, attached to a solid phase. The assay was carried out according to the manufacturer specifications.

Our results demonstrated a concordance index of about $91 \%$ and $100 \%$ between LAT/PAGE and IEARA/PAGE, respectively. IEARA did not detect adenovirus in the analyzed feces. Table 1 shows the number of positive rotavirus samples, as ascertained by LAT.

Among 35 positive fecal samples determined by PAGE, 30 samples were also considered positive by LAT. In our survey, sensitivity of the Slidex Rotavirus Kit $2^{\circledR}$ (BioMérieux) was

Table 1. Comparison of final results on latex agglutination test (LAT) and poliacrylamide gel electrophoresis (PAGE) on the search of rotavirus in fecal matter samples.

\begin{tabular}{lccc}
\hline & \multicolumn{2}{c}{ PAGE } & \\
\cline { 2 - 3 } LAT & positive & negative & total \\
\hline positive & 29 & 1 & 30 \\
negative & 6 & 52 & 58 \\
\hline total & 35 & 53 & 88 \\
& & \\
Parameters for latex & percentage value (\%) \\
agglutination test & & \\
\hline Sensitivity & \multicolumn{2}{c}{82.9} \\
Specificity & & 98.1 \\
Predictive positive value & & 96.7 \\
Predictive negative value & & 89.7 \\
Accuracy & \multicolumn{2}{c}{92.0} \\
\hline
\end{tabular}

higher (82.9\%) than that (68.0\%) described by Marshall et al (7)

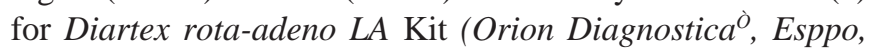
Finland). We also verified that the percentage of false positive reactions about $1.1 \%(1 / 88)$ on LAT was lower than the percentages observed for other kits: $2.7 \%$, Rotalex, Orion Diagnostic Espoo Finland (6) e 2.4\%, Slidex Rotatest (3). Otherwise, rotavirus antigen was not detected by the LAT on six PAGE positives samples, showing a false negative reaction index of about $6.8 \%$ (6/88). These false negatives reactions may be occurring due to many reasons: the monoclonal antibodies that sensitize the latex particle may not be detecting the serotype; the viral title could be lower than the technique sensitivity; the feces may contain unspecific inhibitors or IgA antibodies, resulting in weak agglutination reactions, not detected by the technician $(1,3)$.

The results observed on this work demonstrated good sensitivity (82.9\%) and high specificity (98.1\%). The correlation degree in regard of PAGE results was good (91.0\%), with a high predictive positive value $(96.7 \%)$. These results indicate that the commercial kit used for rotavirus detection on feces performed properly, with great simplicity and speed. However, due to the occurrence of $6.8 \%$ false negative reactions, representing $89.7 \%$ predictive negative value, it is recommended that negative samples on LAT be reevaluated by another assay with higher sensitivity such as IEARA or PAGE. It is important to emphasize that the observed predictive negative value for LAT was lower then that reported in the instructions of the kit used in this work (95.7\%).

The results indicate that the LAT kit used for rotavirus diagnosis presented good sensitivity, high specificity, and easy proceeding, providing fast diagnosis for rotavirus infections. We suggest that samples considered negative by LAT should be analyzed by a more sensitive second assay for minimizing false negative reactions, in order to assure an appropriate diagnosis for rotavirus infections.

\section{RESUMO}

\section{Desempenho do Teste de Aglutinação em Látex para o diagnóstico de gastroenterite aguda por rotavírus}

O objetivo deste trabalho foi determinar o desempenho do teste de aglutinação em látex (TAL), no diagnóstico das gastroenterites agudas em crianças, causadas por rotavírus. $\mathrm{O}$ TAL mostrou boa sensibilidade, especificidade e valor preditivo positivo e devido à sua simplicidade e rapidez, o teste é apropriado para uso em hospitais para o diagnóstico de rotaviroses.

Palavra-chave: Rotavirus, diagnóstico, teste de aglutinação em látex, eletroforese em gel de poliacrilamida 


\section{REFERENCES}

1. Buser, J.; Risch, L.; Rutz, T.; Manang, S.; Munzinger, J. (2001) Comparison of a rotavirus latex agglutination test with two rapid immunochromatographic test devices for detection of rotavirus in human feces. Rev. Eur. J. Clin. Microbiol. Infect. Dis., 20, 295296.

2. Fernandes, J.V. (2000). Rotavirus detection in feces of children with acute diarrhea. J. Ped., 4: 300-304.

3. Ibrahim, O.S.; Sunderland, D.; Hart, C.A. (1990). Comparison of four methods for detection of rotavirus in feces. Trop. Doctor., 20, 30-32.

4. Linhares, A.C. (1997). Rotavirus Infection in Brazil: epidemiology, immunity and potential vaccination. Bras. J. Infect. Dis., 1, 284 293.
5. Linhares, A.C. (2000). Rotavirus Infection in Brazil: epidemiology and challenges for its control. Cad. Saúde Pública, 16, 629-646.

6. Lipson, S.M.; Zelinsky-Papez, K.A. (1989). Comparison of four latex agglutination (LA) and three enzyme-linked immunosorbent assays (ELISA) for the detection of rotavirus in fecal specimens. AJCP. 92, 637-643.

7. Marshall, J.; Botes, J.; Gorrie, G.; Boardman, C.; Gregory, J.; Griffith, J.; Hogg, G.; Dimitriadis, A.; Catton, M.; Bishop, R. (2003). Rotavirus detection and characterization in outbreaks of gastroenteritis in aged-care facilities. J. Clin. Virol., 28, 331-340.

8. Pereira, H.G. et al. (1985). A combined enzyme immunoassay for rotavirus and adenovirus (IEARA). J. Virol. Methods, 10, 21-28.

9. Santos, N.; Gouveia, V. (1994). Improved method for purification of viral RNA from fecal specimen for rotavirus detection. J. Virol. Methods, 46, 11-21. 